\title{
TRUMPING PRECEDENT WITH ORIGINAL MEANING: NOT AS RADICAL AS IT SOUNDS
}

\author{
Randy E. Barnett*
}

Originalism was thought to be buried in the 1980 s with critiques such as those by Paul Brest ${ }^{1}$ and Jeff Powell. ${ }^{2}$ Brest charged that originalism was unworkable, while Powell maintained that originalism was inconsistent with the original intentions of the Founders. ${ }^{3}$ Others raised the moral challenge of why we should be ruled by the "dead hand" of the past. Yet an originalist approach to interpretation has-like a phoenix from the ashes or Dracula from his grave, depending on your point of view-survived into the Twenty-first Century as an intellectual contender. Indeed, it has thrived like no other approach to interpretation. $^{4}$

This remarkable survival is due, in part, to originalism itself having morphed in response to these critiques from its previous preoccupation with the original intentions of the framers to an emphasis on the original public meaning of the text at the time of its enactment. ${ }^{5}$ Determining the public meaning of the words

* Carmack Waterhouse Professor of Legal Theory, Georgetown University Law Center. Permission to photocopy for classroom use is granted.

1. See Paul Brest, The Misconceived Quest for Original Understanding, 60 B.U. L. REV. 204 (1980).

2. See H. Jefferson Powell, The Original Understanding of Original Intent, 98 HARV. L. REV. 885 (1985).

3. The analysis of the next three paragraphs is greatly elaborated in RANDY E. BARNETT, RESTORING THE LOST CONSTITUTION 89-117 (2004).

4. I originally told this story in Randy E. Barnett, An Originalism for Nonoriginalists, 45 LOY. L. REV. 611, 611-29 (1999). The tale has been updated and greatly expanded in Vasan Kesavan \& Michael Stokes Paulsen, The Interpretive Force of the Constitution's Secret Drafting History, 91 GEO. L.J. 1113, 1134-48 (2003) (discussing the contributions to this development played by Robert Bork, Steven Calabresi, Frank Easterbrook, Gary Lawson, John Manning, Michael McConnell, Michael Paulsen, Saikrishna Prakash, Antonin Scalia, Guy Seidman, and others). Given the brevity of this essay, I will not even attempt to give credit where credit is due. Kesavan and Paulsen do a wonderful job of this.

5. See Keith Whittington, The New Originalism, 2 Geo. J.L. \& PUB. POL'Y 599 (2004) (distinguishing the "old originalism" based on original intent and judicial festraint 
of the Constitution is much more practical than discovering the myriad subjective intentions of those who wrote or ratified it. That there is a unique original public meaning is a far more plausible claim than that one can discern a unique original intention from the potentially conflicting intentions of various framers. And it turns out that the Founders themselves practiced a form of original meaning originalism. ${ }^{6}$

Finally, an original public meaning approach can be grounded in the need to impose written constraints on all branches of government. According to this normative defense, we should adhere to the original meaning of the document, not because long dead men have any authority over we the living. We should do so because we, right here and right now, ought to consider a written constitution among the structural features of our Constitution, and this feature would be undermined if any of the branches of government, either alone or together, could alter and weaken the written limitations which have been imposed upon them.

\section{THE INCOMPATIBILITY OF ORIGINALISM AND PRECEDENT}

With these familiar criticisms largely neutralized, what intellectual challenge to originalism is left? Today, the biggest single challenge facing originalists is reconciling originalism with precedent. ${ }^{7}$ The problem can be summarized by the following syllogism:

(1) Originalism amounts to the claim that the meaning of the Constitution should remain the same until it is properly changed.

(2) None of the three branches of government on whom the written Constitution imposes limits should be able to alter these limitations, either alone or in combina-

from the "new originalism" based on public meaning and the need for judges to adhere to it).

6. Although Caleb Nelson questions the degree to which the move to original meaning obviates the various difficulties associated with original intent, he does not deny it mitigates the seriousness of criticisms of originalism that were previously thought to be fatal. See Caleb Nelson, Originalism and Interpretive Conventions, 70 U. CHI. L. REV. $519,553-60(2003)$.

7. Another important theoretical issue confronting originalism is the role of the Founders' interpretive conventions in determining the original meaning of the text. This issue has been insightfully examined by Caleb Nelson in id. I shall not discuss it here. 
tion, without properly amending the Constitution in writing.

(3) For this reason, the Supreme Court cannot change the Constitution which it is sworn to uphold and enforce.

(4) Were the Court mistakenly to decide a case that adopts an interpretation that contradicts the original meaning of the text, and this mistake was entrenched by the doctrine of precedent, then the Supreme Court's interpretation of the text would trump its original meaning.

(5) In this manner, the doctrine of precedent is inconsistent with originalism.

Two possible responses to this syllogism are obvious. The first is to treat the syllogism as a reductio ad absurdum and to reject originalism. The second is to embrace the conclusion of the syllogism as correct and to reject precedent. There are difficulties with each of these options.

The problem with rejecting originalism goes to the normative arguments on its behalf. Accepting that judicial precedent can trump original meaning puts judges above the Constitution they are supposed to be following, not making. If precedent trumps original meaning, then the Constitution would truly be what the Supreme Court says it is, rather than the Supreme Court itself being bound to adhere to the Constitution. In sum, if the normative case for originalism is compelling, then it provides a normative argument for rejecting the doctrine of precedent, where precedent conflicts with original meaning.

The problems with rejecting the doctrine of precedent are several. One difficulty that troubles many an originalist about rejecting precedent is that stare decisis seems important to the rule of law requirement that like cases be treated alike. Most originalists place a high value on the rule of law, which is one reason they care so much about preserving the original meaning of a written constitution. Were precedent to be rejected, the stability of constitutional law might be undermined as each Court considers itself completely free to reach different conclusions about the meaning of the text as time goes by.

But critics of originalism, and indeed even some originalists, would be even more troubled by another consequence of rejecting the doctrine of precedent. Such a rejection would seemingly lead to the rejection of many of the landmark cases most treasured by constitutional law professors, and even by the general 
public. While many examples may come to mind, it is the possibility of rejecting Brown v. Board of Education ${ }^{8}$ that is most troubling and illustrates the difficulty.

Let me hasten to add that I do not think original meaning interpretation is inconsistent with Brown. On this subject, I am influenced by the impressive scholarship of Michael McConnell, though I have not myself independently assessed the evidence or the criticisms that have been offered of his thesis. ${ }^{9}$ Akhil Amar has also provided a powerful account reconciling Brown with the original meaning of the Fourteenth Amendment. ${ }^{10}$ Whereas McConnell's work can be viewed as focusing more on original intent than on original meaning, Amar's analysis seems a straightforward analysis of the public meaning of the text, both then and now. Of course, if the original intentions of the framers of the Fourteenth Amendment were consistent with Brown then a fortiori so too would likely be the original public meaning of the words they chose to enact. Neither writer expressly discusses this distinction, however, as was not uncommon when originalism was in transition. Consequently, a considerable amount of originalist scholarship straddles the line.

In addition, as discussed briefly below, I do not view "separate but equal" as the original meaning of the Fourteenth Amendment. Instead, I consider this doctrine to be a judicial construction of the text that may or may not be consistent with its original meaning. Even if it is consistent, it can nevertheless be rejected in favor of another construction that is also consistent with the original meaning, but which enhances the legitimacy of the Constitution.

$\mathrm{Be}$ all this as it may, my point is only that, if one had to choose between original meaning and Brown, most would choose Brown. Having raised the issue of Brown, however, it is only fair to note how this case reveals that nonoriginalists have their own problems with the doctrine of precedent. For even if Brown could not be justified on originalist grounds, it was a marked departure from the precedent of Plessy v. Ferguson. ${ }^{11}$ It is at least awkward for nonoriginalists to consider the rejection

8. 347 U.S. 483 (1954).

9. See Michael W. McConnell, Originalism and the Desegregation Decisions, $81 \mathrm{U}$. VA. L. REV. 947 (1995); Michael W. McConnell, The Originalist Justification for Brown: A Reply to Professor Klarman, 81 U. VA. L. REV. 1937 (1995)

10. See Akhil Reed Amar, Foreword: The Document and the Doctrine, 114 HARv. L. REV. 26, 55-78 (2000).

11. 163 U.S. $537(1896)$ 
of precedent a reductio ad absurdum of originalism when they themselves would favor rejecting the precedent of Plessy in favor of Brown come hell or high water.

In short, for nonoriginalists (and most everyone else), first comes Brown and only then comes precedent. While different versions of nonoriginalism may be deemed superior if they can better handle Brown than can originalism, it is far from clear that these nonoriginalist theories can better handle the doctrine of precedent. Consider the cases of United States v. Lopez ${ }^{12}$ and United States $v$. Morrison. ${ }^{13}$ These are cases that many law professors would like to see reversed, and it seems that the four dissenting Justices in those cases are still reluctant to consider themselves bound by them. That they are precedent does not seem to mean very much to nonoriginalist professors or Justices. So why should precedent-say of Wickard v. Filburn ${ }^{14}$ to take a case at random-bother originalists overly much if it conflicts with the original meaning of the Commerce Clause? ? $^{15}$

Indeed, many nonoriginalists who now invoke precedent to browbeat originalism themselves appear committed only to the precedents they happen to like, and this is hardly a commitment to the doctrine of precedent at all. In other words, perhaps no one really adheres to anything like a robust doctrine of precedent, so originalists who rejected the doctrine would hardly be unique in this regard. Perhaps originalists are just more candid than their nonoriginalist critics. With the doctrine of precedent rejected to some degree by nearly everyone, the debate would return to the normative and practical merits of originalism on which grounds, I contend, the theory is strong.

Indeed, this discussion highlights the well-known problem with the doctrine of precedent. No one thinks that precedents should last forever. Everyone thinks that some precedent should be rejected. So all theorists, whether originalists or not, place other values above the rule of law concerns that lead them to favor precedent only some of the time. How and when precedent should be rejected remains one of the great unresolved controversies of jurisprudence. It is no wonder that originalists have yet to solve the problem that has so eluded so many for so long.

12. 514 U.S. 549 (1995).

13. 529 U.S. $598(2000)$.

14. 317 US 111 (1942).

15. See Randy E. Barnett, The Original Meaning of the Commerce Clause, $68 \mathrm{U}$. CHI. L. Rev. 101 (2001); Randy E. Barnett, New Evidence of the Original Meaning of the Commerce Clause, 55 ARK. L. REV. 847 (2003). 
Still, originalism does seem to have a special difficulty with precedent. Nonoriginalists can accept the idea that precedent can sometimes bind to some degree, though there is no consensus on how much and when. Originalists seem committed to rejecting precedent altogether. Perhaps originalism can claim the advantage of avoiding the knotty issue of how and when precedent is to be followed, but it does so at the seeming expense of either the rule of law values that support some doctrine of precedent or sanctified precedent such as Brown that all nonoriginalists, and the overwhelming majority of originalists, would like to see upheld.

Perhaps the problem for originalists with precedent boils down to what, for nonoriginalists, is its biggest weakness. If times and moral understanding really have changed so much that the original constitution as amended is simply unacceptable as compared with the constitutional law provided by the rulings of the Supreme Court, this deficiency is revealed by originalism's rejection of morally superior precedent. Notice, however, that when stripped of its ruffles and flourishes this objection to originalism represents the rejection of the written Constitution as enacted-a rejection that Courts and scholars alike are every bit as reluctant to make openly as originalists are reluctant to openly reject certain hallowed precedents.

\section{THE PROPER ROLE OF PRECEDENT WITHIN ORIGINALISM}

I think that accepting originalism means accepting the syllogism provided above. ${ }^{16} \mathrm{~A}$ commitment to originalism is a claim about how the Constitution ought to be interpreted. The normative case for originalism is based, in large measure, on the superiority of the enacted text over the opinions of the branches of government that it is supposed to govern and limit-including

16. Perhaps the first modern originalist to forthrightly reach the conclusion that originalism entails the rejection of the doctrine of precedent was my colleague Gary Lawson. See Gary Lawson, The Constitutional Case Against Precedent, 17 HARV. J.L. \& PUB. POL'Y 23 (1994). For an originalist who agrees, see Michael Stokes Paulsen, The Intrinsically Corrupting Influence of Precedent, 22 CONST. COMMENT. 289 (2005). Indeed, Paulsen thinks the rejection of stare decisis can be accomplished by simple act of Congress. See Michael Stokes Paulsen, Abrogating Stare Decisis by Statute: May Congress Remove the Precedential Effect of Roe and Casey?, 109 YALE L.J. 1535 (2000). Lawson disagrees. See Gary Lawson, Controlling Precedent: Congressional Regulation of Judicial Decision-Making, 18 CONST. COMMENT. 191 (2001). For Paulsen's response, see Michael Stokes Paulsen, Lawson's Awesome (Also Wrong, Some), 18 Const. CoMmENT. 231 (2001). 
the Supreme Court. An originalist simply could not accept that the Supreme Court could change the meaning of the text from what it meant as enacted and still remain an originalist. Yet with some exceptions, ${ }^{17}$ until very recently most originalists have not confronted the issue of precedent directly and certainly not theoretically. In the balance of this essay, I explain why the originalist rejection of precedent is not so radical as it at first appears.

\section{A. NONCONSTITUTIONAL CASES}

First of all, the doctrine of precedent could survive for any or all cases whose outcome does not concern the original meaning of the text. As Justice Scalia has observed, "a very small proportion of judges' work is constitutional interpretation.... (Even in the Supreme Court, I would estimate that well less than a fifth of the issues we confront are constitutional issues-and probably less than a twentieth if you exclude criminal-law cases.)"18 Obviously, in the numerous cases that simply do not turn on constitutional analysis, courts could be as bound by precedent as is deemed appropriate. But even a great many constitutional cases, perhaps most, do not turn on the original public meaning of the text and, in such cases, courts could be bound by precedent as well. Understanding why is crucial to grasping that permitting original meaning to trump precedent is not nearly so radical as it sounds.

\section{B. CONSTITUTIONAL CONSTRUCTIONS}

According to the version of originalism I have identified and defended, the original public meaning of the text governs only to the extent that this meaning can be ascertained and applied to a case or controversy. Sometimes the original meaning of a text is clear and rule-like - the age limits for presidents is the favorite example - and it directly dictates the outcome of a case or controversy. Other times, however, the original meaning is rather abstract, or at a higher level of generality. A contract law

17. See e.g., Lawson, The Constitutional Case Against Precedent, supra note 16; Amar, supra note 10, at 78-89 (discussing “precedent's proper place"); and Nelson, supra note 6, at 588-98 (discussing "originalism and the passage of time").

18. ANTONIN SCAlia, Common-Law Courts in a Civil-Law System: The Role of United States Federal Courts in Interpreting the Constitution and Law, in A MATTER OF INTERPRETATION: FEDERAL COURTS AND THE LAW 3, 13 (1997). 
scholar would refer to the text as vague. ${ }^{19}$ The Due Process Clause is a clause like this.

In response to the problem of vagueness, original intent originalists consult the intentions of the framers to narrow the meaning of seemingly open-ended provisions to constrain the discretion of judges. This stance, however, revives many of the persuasive objections to original intent originalism that the move to original public meaning originalism was meant to avoid.

In contrast, an original meaning originalist can take the abstract meaning as given, and accept that the application of this vague meaning to particular cases is left to future actors, including judges, to decide. The process of applying general abstract provisions to the facts of particular cases by adopting intermediate doctrines is properly called, not interpretation, but constitutional construction. ${ }^{20}$

Some original public meaning originalists would have courts ignore the original meaning of the text when it is insufficiently rule-like. ${ }^{21}$ Suffice it to say that, in my view, for judges to ignore the original meaning of the text because it is inconsistent with some extrinsic notion of the Rule of Law is as improper as ignoring the original meaning of the text because it conflicts with some extrinsic notion of Justice. The original constitutional structure as amended would be radically altered-and for the worse-if all the more abstract or vague provisions of the text were ignored in this way. That the Constitution includes more open-ended or abstract provisions, and thereby delegates discretion to judges, does not justify ignoring these portions of the text. Textual vagueness does, however, argue for courts to adopt more rule-like constitutional constructions or doctrines to put these provisions into effect.

Some constitutional constructions or doctrines may be much better than others in implementing the original meaning of the text, in which case precedent should not stand in the way. For

19. See E. Allan Farnsworth, "Meaning" in the Law of Contracts, 76 YALE L.J. 939, 953-56 (1967).

20. The distinction between constitutional interpretation and construction is elaborated in BARNETT, supra note 3, at 118-30. My discussion there is based on the distinction made in KEITH WHITTINGTON, CONSTITUTIONAL INTERPRETATION: TEXTUAL MEANING, ORIGINAL INTENT, AND JUDICIAL REVIEW 7 (1999).

21. I think this attitude informs Justice Scalia's view that the Ninth Amendment is not justiciable because "the Constitution's refusal to 'deny or disparage' other rights is far removed from affirming any one of them, and even farther removed from authorizing judges to identify what they might be, and to enforce the judges' list against laws duly enacted by the people." Troxel v. Granville, 530 U.S. 57, 91 (2000) (Scalia, J., dissenting). 
example, my case for adopting a Presumption of Liberty - which is a constitutional construction-argues against continuing to adhere to the precedents that established a presumption of constitutionality, as modified by Footnote Four, as further modified by the jurisprudence of "fundamental rights" - the doctrine I call Footnote Four-Plus, which is itself a constitutional construction. $^{22}$ In addition, when two constructions are equally consistent with the original meaning of the text, I have argued that courts should favor constructions that enhance the legitimacy of the Constitution. By "constitutional legitimacy" I mean that quality or qualities that enable a legal system to issue laws that bind in conscience those upon whom they are imposed.

It is easy to imagine, however, that many choices among competing constructions are both equally consistent with original meaning and not clearly preferable on grounds of legitimacy. What proportion of constitutional constructions fit this description I do not know, but I suspect it is quite common. Because the Constitution does not dictate the number of Supreme Court Justices, the number chosen by Congress is a construction. The number at the founding, six, and the present number of nine, are both equally consistent with the text, and neither is to be preferred on grounds of legitimacy. The number zero, however, is certainly inconsistent with the text, as is probably also the number one.

Although there is much more to say about how constitutional construction can be constrained by original meaning while not entirely determined deductively by it, for present purposes it is enough to say this: judicial constructions of the Constitution that are not inconsistent with original meaning may well be subject to the doctrine of precedent. So while the judicially-created doctrine of "content neutrality" is by no means a product of the original meaning of the First Amendment, it is a constitutional construction by which the original meaning of the First Amendment can be applied to concrete cases. Once the doctrine of content neutrality is adopted, there is no originalist objection to it being considered a binding precedent, even if someone proposes a different way to implement the right of freedom of speech.

Indeed, as was suggested above, Separate but Equal could be considered a constitutional construction of the Privileges or

22. See BARNETT, supra note 3, at 224-69 (arguing that the Presumption of Liberty is more consistent with the original meaning of the Ninth and Fourteenth amendments than the doctrine of "Footnote Four-Plus"). 
Immunities Clause or the Equal Protection Clause. Assuming arguendo that the construction of Separate But Equal was consistent with the original meaning of the text-though I am skeptical of this claim-it could become a binding precedent until it is rejected in favor of another construction of these clauses that is equally consistent with its original meaning, but superior on grounds of constitutional legitimacy.

Part of the conundrum over Brown may well be the assumption, by critics of originalism perhaps even more so than by originalists, that the original meaning of the Equal Protection Clause is determinate enough to dictate Plessy and reject Brown. Whether or not this claim is true of original intent originalism, I doubt it is true of original meaning originalism. Nor would it be surprising to find that some critics of originalism seek out its least plausible version so as to reject originalism as unacceptable. Indeed, given the present consensus about Brown, it may be that some critics of originalism relish the claim that the original meaning of the Fourteenth Amendment dictates the doctrine of Separate But Equal and the rejection of Brown so they can use this consequence as a cudgel against originalists.

\section{RELIANCE CLAIMS}

Another role for precedent within originalism concerns reliance claims. An originalist need not reject legal claims made by particular persons made in reliance on mistaken precedent. It is possible that citizens have reasonably relied upon erroneous decisions of the past in a manner that should be protected. The most obvious and easy example of this is the Social Security system. Even if we assume that, for some reason, the Social Security Act is unconstitutional because it violates the original meaning of the Constitution, the government might still be obligated to make good on its promises to those who have relied to their detriment upon them.

The problem with the reliance argument is not with its validity, but that it is usually applied much too broadly to cases where people have "relied" in much too inchoate a sense. It is especially misapplied to the reliance of governmental actors or interest groups on the continued existence of unconstitutional powers or institutions. Nevertheless, in my view, a commitment to original meaning over precedent does not entail a commitment to rejecting properly tailored reliance claims by individual citizens. 


\section{EPISTEMIC CONSIDERATIONS}

In addition, Akhil Amar has plausibly suggested that, within originalism, precedent can play an "epistemic" role:

Given the Court's clear constitutional design, it seems permissible for the Court to give its past decisions a rebuttable presumption of correctness. A past case may properly control until proven wrong, with those challenging it saddled with the burden of proof. Furthermore, a Justice may rightly give a precedent epistemic weight in deciding whether the burden is met. Even if her first reaction is that the precedent is wrongly decided as a documentarian matter, the very fact of the prior decision may persuade her that her first reaction is mistaken.

So when the claim is made that original meaning is inconsistent with a previous judicial decision, courts may give their prior decision a benefit of the doubt. However, any epistemic "presumption of correctness" should only be extended to previous decisions that actually attempted to discern original meaning. Decisions that abjure original meaning can hardly be presumed to have been correctly decided on originalist grounds.

\section{E. ORIGINAL AMIBIGUITIES}

Finally, Caleb Nelson has proposed a role within originalism for early precedents that would be permanent in the sense that they should not be reversed by later interpreters. He contends that the indeterminacy of original meaning can properly be "liquidated" by early decisions of the ratification conventions, Congress, and the courts. ${ }^{24}$ His account of original meaning would accord a role for the Founders' interpretive convention that early precedent can "fix" the meaning of terms whose original meaning was indeterminate when enacted. As I understand it, Professor Nelson's proposal concerning "liquidation" of meaning is limited to rectifying an initial indeterminacy in original meaning. It would not allow for early precedent to trump a contrary determinate original meaning of the text. Still, very early decisions and practices can "fix" the original meaning of the text where the text is open-ended and, once fixed, this meaning cannot then be trumped by later judicial decision. ${ }^{25}$

23. Amar, supra note 10 , at 81 . Amar used the term "documentarian" to refer to a method of interpretation akin to what I and others now describe as original public meaning originalism.

24. See Nelson, supra note 6, at 525-53.

25. See id. at 521 . 
For example, he plausibly shows how the Ex Post Facto Clause was originally ambiguous about whether it applied to all laws or only to criminal penalties. ${ }^{26} \mathrm{By}$ "ambiguous" I mean that there is equally good historical evidence in support of both of these meanings, such that (so far as we know from the evidence) either meaning would have been reasonable. ${ }^{27} \mathrm{He}$ then proposes that this ambiguity in original meaning could properly be, and was, fixed by the early decades of congressional and judicial practice limiting the clause to criminal penalties. ${ }^{28}$ The fact that there is evidence that supports a broader original meaning of the clause - which is why the clause had more than one plausible meaning - could not afterwards be used by courts to change the meaning fixed by early precedent. Here then is a further role for precedent in originalism, but a type of irreversible precedent that binds all future interpreters.

If Professor Nelson is correct about this "liquidating" role of precedent within originalism, it then becomes important to distinguish terms that are ambiguous from those that are vague. ${ }^{29}$ A provision can be vague because, though its meaning is determinate, it is unclear whether that meaning includes a particular object. For example, while the original meaning of "arms" in the Second Amendment undoubtedly refers to weapons, including firearms and swords, does this term also extend to artillery pieces (which were in existence at the time of the framing) or surface-to-air missiles (which were not)? All terms are vague to a greater or lesser degree depending on the context, so this sort of problem is not uncommon.

In contrast, a provision is ambiguous if it has more than one possible meaning. For example, did the term "arms" in the Second Amendment refer to weapons or to the appendages to which our hands are attached? Most terms are not ambiguous in context. Although potential ambiguity can often be resolved by historical evidence, Professor Nelson's discussion of the Ex Post Facto Clause provides an example of a potential ambiguity that appears historically irresolvable.

26. See especially id. at 580, n. 246 .

27. Cf. Raffles v. Wichelhaus, 2 Hurl. \& C. 906 (Court of Exchequer 1864) (insufficient evidence to favor one ship named "Peerless" over the other).

28. See Nelson, supra note 6, at 578-88.

29. In his article, Professor Nelson does not seem to draw a distinction between these two distinct sources of linguistic indeterminacy.

30. In contrast, his discussion of "cruel and unusual" punishments (supra note 6 at 544-47) might concern either ambiguity - e.g. did the term "unusual" refer to punishments that were unusual at the time of the founding or punishments that are unusual at 
Professor Nelson's proposal that initial practice can provide a precedent to fix original meaning that was indeterminate when enacted is more plausible when dealing with ambiguity than vagueness. When we cannot tell whether a term meant $X$ or $Y$ when it was enacted, early practice favoring $X$ over $Y$ might be an interpretive convention that clarifies original meaning in a manner that is compatible with the normative case for originalism. In contrast, when the original meaning of the term is $X$, and $X$ is vague, the application of $X$ to a particular object could be considered a matter of constitutional construction that is not permanently fixed by early precedent. Instead, original meaning can be determinate at a higher level of generality, while the application of this meaning to particular objects is left to the discretion of future decision makers. These future constitutional constructions can be subject to the ordinary doctrine of precedent that, once adopted by the Supreme Court, are followed by future Justices, but which can also be overturned when a later Court is convinced that an earlier decision was manifestly in error.

\section{CONCLUSION}

In this essay, I hope to have explained why there is much room for the doctrine of precedent in originalism. It is not incompatible with original public meaning originalism to adhere to precedent in cases involving (a) nonconstitutional issues, (b) matters of constitutional construction, (c) detrimental reliance by identifiable individuals, (d) epistemic concerns about the correctness of originalist claims, and perhaps also (e) where the text was originally ambiguous. After all this, some may then wonder what bite is left in originalism?

The answer, while obvious, bears emphasis: Where a determinate original meaning can be ascertained and is inconsistent with previous judicial decisions, these precedents should be reversed and the original meaning adopted in their place. That original meaning would require a change in current doctrine, even where contrary to precedent, is evidenced by the resistance towards originalism still manifested by nonoriginalists wishing to preserve the status quo. Apparently the shoe still squeezes.

Knowing the degree to which a commitment to originalism entails the rejection of the doctrine of precedent may well influ-

the time the standard is being applied? - or vagueness-e.g. is a particular punishment "unusual" under the proper standard? - or both. 
ence the degree to which originalism is deemed acceptable by academics, judges, and the general public. For this reason, it is important to make clear that a commitment to following original meaning where it conflicts with judicial precedent is far less radical a stance than critics of originalism, and perhaps even some originalists, assume. 